\title{
ANALISIS PENINGKATAN PARTISIPASI AKTIF MAHASISWA MELALUI PENERAPAN MODEL PEMBELAJARAN KOOPERATIF DENGAN METODE KANCING WARNA PADA MATA KULIAH STRATEGI BELAJAR MENGAJAR
}

\author{
Nur Lina Safitri \\ Institut Teknologi dan Sains Nahdlatul Ulama Pasuruan \\ e-mail: nurlinasafitri.nls@gmail.com
}

\begin{abstract}
Abstrak: Peran serta mahasiswa dianggap penting dalam pembelajaran. Namun saat ini mahasiswa di Institut Teknologi Nahdlatul Ulama Pasuruan belum dapat dikategorikan sebagai mahasiswa yang aktif. Kondisi saat ini mahasiswa belum memiliki kesadaran pentingnya kemauan untuk ikut aktif dalam pembelajaran. Mahasiswa cenderung menunggu informasi dari dosen tanpa memiliki keinginan untuk mencari sumber informasi sendiri. Saat pembelajaran dimulai, akibatnya mereka seperti belum siap terlihat dari penjelasan yang harus diulang berkali kali dalam setiap materi. Tujuan dari penerapan model pembelajaran kooperatif dengan metode kancing warna adalah sebagai salah satu bentuk upaya dalam menigkatkan partisipasi keaktifan mahasiswa dalam kegiatan belajar mengajar. Penelitian ini merupakan penelitian tindakan kelas (PTK) yang bertujuan untuk meningkatkan partisipasi keaaktifan mahasiswa saat kegiatan belajar mengajar berlangsung. Penelitian ini dilakukan melalui 3 siklus. Pada masing-masing siklus, kegiatan yang dilakukan meliputi perencanaan, pelaksanaan tindakan, observasi, evaluasi serta refleksi. Pengambilan data pada penelitian ini menggunakan lembar observasi mahasiswa dan dosen, angket respon mahasiswa, dokumentasi, wawancara serta studi literatur.Subjek penelitian ini adalah mahasiswa Program Studi Pendidikan Biologi sebanyak 21 orang. Hasil penelitian menunjukkan bahwa Peningkatan partisipasi keaktifan mahasiswa terlihat dari jumlah mahasiswa yang berpartisipasi aktif dalam bentuk kegiatan mengajukan pertanyaan dalam diskusi, mengutarakan pendapat sebagai upaya untuk membantu kelompok presenter dalam menjawab serta beberapa sanggahan terhadap jawaban presenter yang mereka anggap kurang tepat. Pada pertemuan pertama sebanyak 7 mahasiswa, pertemuan kedua sebanyak 15 mahasiswa dan pertemuan ketiga sebanyak 21 mahasiswa. Hasil tersebut berbanding lurus dengan banyaknya frekuensi partisipasi dosen dalam setiap pembelajaran dimana mengalami penurunan dari pertemuan pertama sebanyak $11 \mathrm{kali}, 7 \mathrm{kali}$ dan 2 kali dilihat dalam satu pertemuan.
\end{abstract}

Kata Kunci : Keaktifan Mahasiswa, Strategi Belajar Mengajar,Pembelajaran Kooperatif.

Abstract: Student participation is considered important in learning. But currently students at the Nahdlatul Ulama Institute of Technology in Pasuruan have not yet been categorized as active students. The purpose of the application of cooperative learning models with the color button method is as a form of effort in increasing the participation of student activeness in teaching and learning activities. This research is a classroom action research (PTK) which aims to increase the participation of student activeness when teaching and learning activities take place. This research was conducted through 3 cycles. In each cycle, the activities carried out include planning, action, observation, evaluation and reflection. Data retrieval in this study uses student and lecturer observation sheets, student response questionnaires, documentation, interviews and literature studies. The subjects of this study were 21 Biology Education Study Program students. The results showed that the increase in student activeness participation was seen from the number of students who actively participated in the form of activities asking questions in the discussion, expressing 
opinions as an effort to help the presenter group in answering and some objections to the presenter's answers that they considered inappropriate. At the first meeting there were 7 students, the second meeting was 15 students and the third meeting was 21 students. These results are directly proportional to the number of frequency of lecturer participation in each learning experience which has decreased from the first meeting 11 times, 7 times and 2 times in one meeting.

Keywords: Student Activity, Teaching and Learning Strategies, Cooperatif Learning

\section{PENDAHULUAN}

Pembelajaran merupakan kegiatan
yang dilaksanakan oleh pendidik (Dosen)
untuk mengarahkan mahasiswa dalam
belajarbaik di dalam kelas maupun di luar
kelas. Dalam kegiatan pembelajaran saat ini,
dituntut untuk mengganti pola pikir
pembelajaran dari Teacher centered menjadi
Student Centered(Dani, et al., 2016). Pembelajaran Student Centered merupakan pembelajaran dimana peserta didik (Mahasiswa) bebas mencari informasi mengenai materi dalam pembelajaran seluasluasnya (Suprijono, 2012). Kebebasan tersebut bertujuan agar mahasiswa dapat memperoleh beragam informasi sehigga dapat memicu keaktifan mahasiswa di dalam kelas saat pembelajaran. Mahasiswa yang terlibat aktif dalam pembelajaran akan memperoleh lebih banyak pengalaman karena mereka tidak hanya mendengar sehingga memori yang berkaitan dengan pembelajaran akan tersimpan lebih lama (Untarti \& Kusuma, 2018).

Namun, pada penerapannya tidak sesuai dengan apa yang diharapkan. Pembelajaran di dalam kelas cenderung di dominasi oleh beberapa mahasiswa saja, buktinya hanya terdapat $27,5 \%$ mahasiswa yang menganggap pentingnya partisipasi dalam pembelajaran. Akibatnya, keaktifan dalam pembelajaran tidak merata pada semua mahasiswa (Untarti \& Kusuma, 2018). Hal tersebut disebabkan karena tidak semua mahasiswa merasa perlu untuk mencari beragam informasi mengenai materi dalam perkuliahan khususnya pada mata kuliah strategi belajar mengajar sehingga mereka tidak memiliki bahan informasi yang digunakan saat pembelajaran (Amelia, et al., 2014).

Salah satu cara yang dapat digunakan untuk mengatasi hal tersebut adalah menerapkan model pembelajaran kooperatif dengan menggunakan metode kancing warna. Model pembelajaran kooperatif merupakan model pembelajaran dengan situasi pengelompokan mahasiswa yang dilakukan secara acak sehingga kemampuan kognitif mahasiswa beragam (Afianti, et al., 2017). Model pembelajaran kooperatif ini mengedepankan model pembelajaran diskusi kelompok sehingga semua mahasiswa yang tergabung dalam beberapa kelompok memiliki keharusan untuk mengungkapkan pendapatnya (Amelia, et al., 2014). Perpaduan antara model pembelajaran kooperatif dengan metode kancing warna diharapkan dapat meningkatkan peran serta aktif mahasiswa dalam pembelajaran.

Metode kancing warna dinilai dapat menyamaratakan keaktifan mahasiswa. Sebanyak 21 mahasiswa dari 30 mahasiswa mengalami peningkatan kemampuan bertanya dalam kelas. Kemampuan lain juga dijelaskan bahwa penggunaan kancing warna dapat meningkatkan rasa percaya diri mahasiswa karena mereka merasa dihargai dalam pembelajaran. (Karyana, 2013). Hal tersebut dapat terlihat dari penggunaan metode kancing warna dimana semua mahasiswa 
menerima kancing warna dan memiliki kesempatan yang sama untuk mengutarakan pendapatnya (Afianti, et al., 2017). Hal tersebut dapat diartikan bahwa semua anggota kelompok memiliki tujuan yang sama dan kepentingan yang sama sehingga dapat tercipta hubungan timbal balik (Kagan, 1998). Tujuan dari penerapan model pembelajaran kooperatif menggunakan metode kancing warna adalah untuk meningkatkan partisipasi aktif mahasiswa sehingga keseluruhan mahasiswa di dalam kelas (21 mahasiswa) mampu mengutarakan pendapatnya pada setiap diskusi yang dilaksanakan. Pendapat yang diutarakan mahasiswa dapat berupa pertanyaan, kalimat yang bersifat bantuan jawaban dan kalimat sanggahan terhadap jawaban dari pertanyaan. Penelitian ini akan dilaksanakan dalam tiga siklus.

\section{TINJAUAN PUSTAKA}

Strategi belajar mengajar merupakan salah satu mata kuliah yang di program oleh mahasiswa prodi Pendidikan Biologi Institut Teknologi dan Sains Nahdlatul Ulama pada semester genap. Mata kuliah ini bekaitan dengan hal-hal yang harus dipelajari mahasiswa sebagai calon pendidik dalam melakukan kegiatan belajar mengajar. Dalam mata kuliah strategi belajar mengajar, topik yang dipelajari berkaitan dengan konsep belajar.

Belajar merupakan keadaan dimana seseorang yang berawal dari tidak tahu menjadi tahu. Maksudnya adalah seseorang dikatakan belajar jika terjadi perubahan baik sikap, pengetahuan maupun tingkah laku. Belajar juga dapat dikatakan sebagai akibat dari pengalaman siswa dan interaksi dengan lingkungannya (Hamdani, 2011). Setelah belajar, konsep yang diajarkan yaitu mengajar. Mengajar dapat diartikan sebagai suatu kegiatan yang dilakukan oleh pendidik untuk melatihkan atau memberikan informasi yang berkaitan dengan topik tertentu pada siswa sebagai peserta didik. Hal tersebut terkait dengan konsep pembelajaran dimana dapat diartikan sebagai proses interaksi yang terjadi antara pendidik, peserta didik dan sumber belajar dalam suatu lingkungan.

Strategi belajar mengajar berkaitan dengan metode dan model pembelajaran. Metode dalam pembelajaran cukup beragam, diantaranya pembelajaran dengan metode ceramah, pembelajaran interaktif, pembelajaran dengan metode demonstrasi, pembelajaran dengan metode diskusi, metode ceramah, metode simulasi, dll (Huda, 2011). Dalam berbagai metode tersebut, terdapat pula berbagai model pembelajaran yang biasa diaplikasikan, diantaranya model pembelajaran kooperatif dengan berbagai tipe yaitu STAD, Jigsaw, Number Head Together, Think Pair Share, dll (Sharan, 2012). Model pembelajaran tersebut dilakukan dengan tujuan untuk menciptakan suasana pembelajaran yang aktif.

Pentingnya keaktifan mahasiswa dalam kegiatan belajar mengajar membuat dosen harus memberikan perhatian ekstra. Mahasiswa yang aktif dalam kegiatan belajar mengajar dapat meningkatkan daya pikir sehingga kemampuan mahasiswa dalam menalar dan memecahkan masalah terasah. Peningkatan keaktifan mahasiswa dalam situasi belajar mengajar dapat merubah perilaku mahasiswa yang awalnya pasif menjadi mahasiswa aktif. Semakin tinggi peningkatan keaktifan mahasiswa, maka kegiatan belajar mengajar akan menjadi lebih hidup. Hal tersebut terjadi karena siswa telah mampu menghilangkan rasa takut mereka baik dalam berpendapat maupun mencari solusi atas suatu topik dalam diskusi.

Salah satu penyebab yang mengakibatkan mahasiswa pasif adalah masih adanya sikap dominan pada guru, sehingga dalam pembelajaran terlihat guru merupakan satu-satunya sumber informasi bagi mahasiswa (Dani, et al., 2016). Permasalahan tersebut terjawab dengan adanya model 
pembelajaran kooperatif. Pembelajaran kooperatif merupakan pembelajaran yang membebaskan mahasiswa atau peserta didik dalam memadukan pikiran dan ide masingmasing anggota kelompok sehingga terbentuk suatu kesepakatan yang selanjutnya diungkapkan dalam forum diskusi kelas. Tugas dosen sebagai pendidik agar pembelajaran kooperatif ini berjalan sesuai dengan sintaksnya adalah sebagai fasilitator, buka lagi sebagai sumber informasi utama.

Pembelajaran kooperatif melibatkan seluruh siswa yang turut serta dalam kegiatan belajar mengajar. Pembelajaran kooperatif dianggap belum tuntas jika terdapat beberapa mahasiswa yang belum memahami topik materi pada hari itu (Afianti, et al., 2017). Ciri dari diaplikasikannya pembelajaran kooperatif adalah terlibatnya setiap anggota dalam diskusi, adanya interaksi baik dalam satu kelompok, maupun dengan kelompok lain, setiap anggota kelompok memiliki tanggung jawab yang sama atas kelompoknya, dan interaksi dosen sebagai pendidik dengan mahasiswa hanya terjadi seperlunya bukan disepanjang kegiatan belajar mengajar (Slavin, 2010).

Tujuan dari model pembelajaran kooperatif adalah melatih kemampuan mahasiswa untuk menerima perbedaan baik kemampuan maupun ketidakmampuan orang lain (Isjoni, 2012)\&(Huda, 2011). Hal tersebut akan memunculkan sikap toleransi pada mahasiswa. Peluang besar yang didapat oleh mahasiswa saat menerapkan model pembelajaran kooperatif adalah akan munculnya perasaan saling menghargai dan saling bergantung demi tercapainya tujuan yang sama yaitu keberhasilan kelompok (Huda, 2011). Tujuan lain yang dapat mengembangkan ketrampilan sosial adalah membiasakan mahasiswa untuk terampil dalam melakukan kerjasama, kolaborasi, menghargai pendapat orang lain serta sikap rendah hati dalam menerima keputusan Bersama meskipun keputusan tersebut bertentangan dengan pendapatnya (Sharan, 2012).

Langkah-langkah yang diterapkan oleh dosen saat akan melakukan pembelajaran kooperatif diawali dengan menyampaikan tujuan pembelajaran pada mahasiswa. Tujuannya adalah agar mahasiswa mengetahui manfaat yang dapat diperoleh setelah mengikuti pembelajaran dengan topik yang telah ditentukan oleh dosen. Selanjutnya dosen perlu menyajikan beberapa informasi yang terkait dengan topik pembelajaran sehingga siswa mendapatkan informasi awal mengenai topik yang akan dipelajari. Kemudian dosen melakukan pembagian kelompok yang beranggotakan 3-4 orang dalam satu kelompok. Pembagian kelompok bertujuan agar setiap anggota kelompok mendapatkan tugasnya masing-masing, sehingga informasi mengenai topik yang akan dibahas lengkap karena adanya sumbangsih pemikiran dari beberapa orang. Langkah selanjutnya adalah dosen membimbing kelompok mahasiswa dalam belajar. Tugas dosen pada langkah ini hanya membimbing, yang artinya hanya memberikan beberapa petunjuk yang dirasa perlu sehingga diskusi mahasiswa tetap berada pada jalur yang semestinya. Setelah itu, dosen melakukan kegiatan evaluasi yang berkaitan dengan materi yang dipelajari hari itu. Evaluasi tidak hanya dilakukan dalam bentuk tes, tetapi dapat pula dilakukan dalam bentuk presentasi hasil diskusi dari masing-masing kelompok. Tahap terakhir dalam pembelajaran kooperatif adalah dosen memberikan penghargaan kepada kelompok mahasiswa yang dirasa memiliki penampilan paling baik diantara kelompok lain. Tujuan dari pemberian penghargaan adalah supaya kelompok mahasiswa lain akan memperbaiki kinerja mereka sehingga muncul motivasi dalam diri masing-masing mahasiswa untuk lebih aktif dalam berdiskusi maupun mencari informasi.

Upaya yang dilakukan dosen dalam merubah kemampuan mahasiswa dalam 
berkelompok dan berdiskusi sebagai upaya meningkatkan keaktifan mahasiswa beragam, salah satunya memadukan dengan metode kancing warna. Penerapan metode kancing warna ini dapat memberikan kesempatan yang sama kepada semua mahasiswa untuk berpendapat (Afianti, et al., 2017). Secara tidak langsung, metode ini memaksa mahasiswa untuk berperan aktif dalam proses berjalannya diskusi. Langkah yang dilakukan dosen saat melakukan metode kancing warna ini diawali dengan dosen menyediakan wadah yang berisi beberapa kancing yang memiliki warna berbeda. Sebelum diskusi dimulai, setiap ketua kelompok mengambil salah satu kancing warna dimana masing-masing warna kancing memiliki tugas yang berbeda. Selanjutnya setiap anggota kelompok harus mengungkapkan pendapatnya sesuai dengan tugas (tergantung warna kancing). Setiap anggota kelompok harus mengungkapkan pendapatnya secara bergiliran.

Keunggulan dari pembelajaran yang menggunakan metode kancing warna adalah menjadikan suasana kelas menjadi lebih meriah sehingga semua siswa antusias dalam mengikuti kegiatan belajar mengajar (Amelia, et al., 2014)\&(Karyana, 2013). Namun, kelemahan yang muncul dari metode kancing warna ini adalah kegiatan belajar mengajar memerlukan waktu yang lebih lama karena beberapa siswa yang belum siap berpendapat cenderung mengakibatkan terjadinya perpanjangan waktu (Karyana, 2013).

\section{METODE PENELITIAN}

Penelitian dilakukan di Institut Teknologi dan Sains Nahdlatul Ulama (ITSNU) Pasuruan Jl. Raya Warung Dowo Komplek Perkantoran PCNU Kabupaten Pasuruan, Jawa Timur yang dilaksanakan pada 3 (tiga) kali pertemuan di semester genap. Objek penelitian adalah seluruh mahasiswa program studi Pendidikan Biologi angkatan pertama yang memprogram mata kuliah Strategi Belajar Mengajar di semester genap (2) tahun akademik 2019/2020 sebanyak 21 orang. Teknik pengumpulan data yang dilakukan dalam penelitian ini terdiri dari pengisian lembar observasi dosen dan mahasiswa, wawancara dengan mahasiswa serta lembar partisipasi mahasiswa.

Jenis penelitian yang dipilih adalah Penelitian Tindakan Kelas (PTK). Tujuan dari PTK adalah mencari solusi atau perbaikan atas suatu permasalahan yang muncul dalam kegiatan pembelajaran (Asmani,2011). PTK merupakan jenis penelitian tindakan berbentuk investigasi yang bersifat reflektif partisipatif, kolaboratif dan spiral dimana memiliki tujuan sebagai perbaikan sistem, metode kerja, proses, isi, kompetensi dan situasi. Penelitian Tindakan Kelas ini terdiri dari tiga siklus, antara lain (a) tahap perencanaan yang terdiri dari perencanaan RPS serta persiapan lembar observasi baik untuk pendidik dan untuk siswa; dan tahapan kedua yaitu (b) pelaksanaan (Kusnandar, 2012).

Teknik pengumpulan data diperoleh dari lembar hasil observasi dosen dan mahasiswa, dokumentasi dan studi literatur. Teknik pengolahan data dan analisis data pada penelitian ini menggunakan analisis deskriptif dimana analisis ini dilakukan pada keadaan dan gejala yang dijabarkan sesuai dengan kenyataan pada waktu penelitian tindakan ini

dilakukan sampai pada berakhirnya penelitian.

\section{HASIL DAN PEMBAHASAN}

Hasil penelitian penerapan model
pembelajaran kooperatif
menggunakan metode kancing warna
mendapatkan hasil peningkatan keaktifan
mahasiswa yang signifikan. Peningkatan
keaktifan mahasiswa dapat diketahui pada
diagram dan tabelberikut:

Tabel 1. Daftar Pertanyaan dan Persentase Angket Respon Mahasiswa 


\begin{tabular}{|c|c|c|c|c|}
\hline No & Pertanyaan & P I & P II & P III \\
\hline 1 & $\begin{array}{l}\text { Saya } \\
\text { memberikan } \\
\text { pendapat setiap } \\
\text { diskusi pada } \\
\text { kelompok saya }\end{array}$ & $30 \%$ & $66 \%$ & $90 \%$ \\
\hline 2 & $\begin{array}{l}\text { Menyelsaikan } \\
\text { tugas yang } \\
\text { sudah diberikan } \\
\text { sangat } \\
\text { mendorong saya } \\
\text { supaya aktif } \\
\text { dalam diskusi } \\
\text { kelompok }\end{array}$ & $30 \%$ & $67 \%$ & $85 \%$ \\
\hline 3 & $\begin{array}{l}\text { Pendapat dari } \\
\text { teman } \\
\text { sekelompok } \\
\text { selalu dijadikan } \\
\text { bahan diskusi }\end{array}$ & $45 \%$ & $79 \%$ & $87 \%$ \\
\hline 4 & $\begin{array}{l}\text { Menghargai } \\
\text { pendapat orang } \\
\text { lain }\end{array}$ & $50 \%$ & $93 \%$ & $95 \%$ \\
\hline 5 & $\begin{array}{l}\text { Saya } \\
\text { menyelsaikan } \\
\text { tugas dengan } \\
\text { cara diskusi } \\
\text { kelompok }\end{array}$ & $45 \%$ & $79 \%$ & $80 \%$ \\
\hline 6 & $\begin{array}{l}\text { Saya membantu } \\
\text { teman mencari } \\
\text { jawaban yang } \\
\text { benar }\end{array}$ & $35 \%$ & $74 \%$ & $85 \%$ \\
\hline 7 & $\begin{array}{l}\text { Saya merasa } \\
\text { senang bekerja } \\
\text { dalam } \\
\text { kelompok }\end{array}$ & $45 \%$ & $75 \%$ & $89 \%$ \\
\hline 8 & $\begin{array}{l}\text { Saya merasa } \\
\text { berpartisipasi } \\
\text { dalam diskusi } \\
\text { kelompok } \\
\text { merupakan hal } \\
\text { yang } \\
\text { membosankan }\end{array}$ & $79 \%$ & $50 \%$ & $44 \%$ \\
\hline 9 & $\begin{array}{l}\text { Saya merasa } \\
\text { kurang percaya } \\
\text { diri terhadap } \\
\text { pertanyaan yang } \\
\text { saya lontarkan }\end{array}$ & $85 \%$ & $56 \%$ & $20 \%$ \\
\hline 10 & $\begin{array}{l}\text { Saya merasa } \\
\text { kurang percaya } \\
\text { diri terhadap } \\
\text { kalimat } \\
\text { sanggahan yang } \\
\text { saya utarakan }\end{array}$ & $90 \%$ & $50 \%$ & $23 \%$ \\
\hline
\end{tabular}


membawa dampak yang sesuai dengan tujuannya yaitu meningkatkan keaktifan mahasiswa sehingga mereka menjadi individu yang memiliki sikap toleransi dan mau mendengar pendapat orang lain (Huda, 2011).

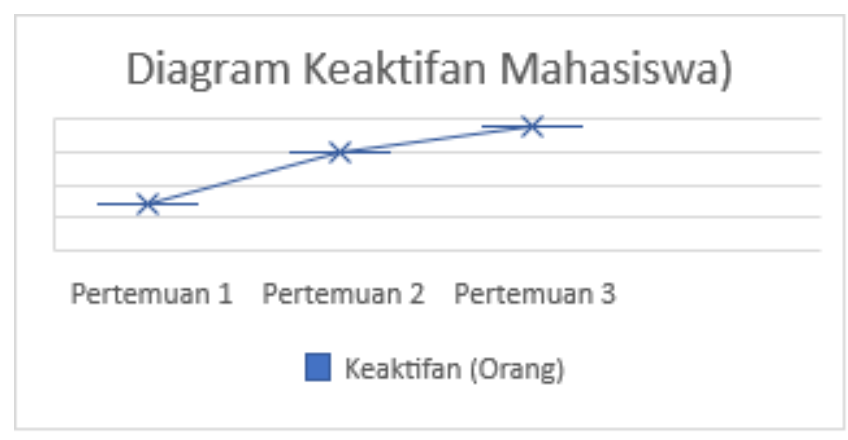

Gambar1. Persentase Peningkatan Keaktifan Mahasiswa

Berdasarkan Gambar1, dapat diketahui bahwa keaktifan mahasiswa Pendidikan Biologi pada mata kuliah Strategi Belajar Mengajar mengalami peningkatan. Hal tersebut dapat dibuktikan dari jumlah mahasiswa yang berpartisipasi aktif pada setiap pertemuan berdasarkan observasi yang dilaksanakan oleh observer dimana pada pertemuan pertama jumlah siswa yang aktif berjumlah 7 orang dimana terdapat 2 orang yang mengajukan pertanyaan, 3 orang membantu menjawab dan 2 orang menyanggah jawaban yang sudah diutarakan; pada pertemuan kedua bertambah menjadi 15 orang ada 8 mahasiswa mengajukan pertanyaan, 4 orang membantu presenter dalam menjawab pertanyaan dan 3 orang berani menyanggah jawaban; pada pertemuan ketiga meningkat menjadi 19 orang dimana ada 11 mahasiswa bertanya, 5 mahasiswa memberanikan diri untuk membantu menjawab dan 3 orang berani menyanggah jawaban. Keadaan yang muncul selama proses belajar mengajar berlangsung sesuai dengan kelebihan yang dimiliki oleh model pembelajaran kooperatif yaitu keadaan kelas menjadi meriah dan menyenangkan sehingga membuat mahasiswa semakin tertarik dan tidak ragu untuk aktif berpendapat dalam diskusi (Amelia, et al., 2014)\&(Karyana, 2013).

Tabel 2. Observasi Dosen

\begin{tabular}{|c|c|}
$\begin{array}{c}\text { Pertemuan } \\
\text { Ke- }\end{array}$ & $\begin{array}{c}\text { Jumlah Partisipasi Dosen dalam } \\
\text { satu pertemuan }\end{array}$ \\
\hline I & $11 \mathrm{kali}$ \\
\hline II & $7 \mathrm{kali}$ \\
\hline III & $2 \mathrm{kali}$ \\
\hline
\end{tabular}

Berdasarkan pada tabel 1, dapat dijelaskan bahwa jumlah partisipasi dosen sebagai pendidik dalam satu kali pertemuan menurun. Hal tersebut dapat dilihat pada angka jumlah partisipasi dosen yang semakin kecil dimana pada pertemuan pertama dosen memancing mahasiswa agar dapat aktif dalam kegiatan belajar mengajar sebanyak 11 kali, pertemuan kedua aktivitas tersebut menurun menjadi 7 kali dan pada pertemuan ketiga kembali mengalami penurunan yaitu 2 kali. Menurunnya jumlah partisipasi dosen dalam upaya memancing keaktifan atau partisipasi mahasiswa ini dapat diartikan bahwa mahasiswa mengalami peningkatan keaktifan pada setiap pertemuan. Cara yang dilakukan dosen dalam memancing keaktifan mahasiswa antara lain berupa pertanyaan yang berisi petunjuk yang mengarah pada materi yang sedang dipelajari. Selain itu, perlakuan yang diberikan antara pertemuan 1,2 dan 3 berbeda. Perbedaan tersebut diartikan bahwa setiap selesai satu pertemuan, dosen dan observer melakukan evaluasi sehingga adanya perbaikan terhadap pemberian petunjuk pada pertemuan selanjutnya. Evaluasi yang dilakukan observer sejalan dengan perubahan pandangan cara mengajar dimana saat ini dtuntut untuk lebih melibatkan mahasiswa dalam pembelajaran (Student Centered) daripada dominasi guru dalam kegiatan belajar mengajar (Dani, et al., 2016).

Peningkatan keaktifan mahasiswa yang dilihat berdasarkan hasil angket selama tiga (3) pertemuan, observasi terhadap dosen 
dan mahasiswa terjadi dikarenakan meningkatnya rasa percaya diri pada mahasiswa, munculnya perasaan dihargai setiap mengutarakan pendapat, meningkatkatnya kemampuan dalam berbicara di depan kelas dalam rangka penyampaian pertanyaan maupun kemampuan dalam memberikan bantuan jawaban terhadap presenter dalam diskusi (Afianti et al, 2017). Keterlibatan mahasiswa dalam pembelajaran dapat memicu peran serta aktif mahasiswa pada setiap pertemuan. Keaktifan tersebut dapat membuat suasana pembelajaran menjadi semakin menyenangkan. Keunggulan lain yang muncul dari keaktifan mahasiswa adalah mereka dapat mengingat konsep suatu materi dalam perkuliahan lebih lama (long term memory) selain itu juga dapat meningkatkan aspek kemampuan berpikir tingkat tinggi.

\section{SIMPULAN}

Berdasarkan pada hasil penelitian yang telah diperoleh, maka dapat disimpulkan bahwa:

1. Terdapat peningkatan partisipasi keaktifan mahasiswa Pendidikan Biologi pada Mata Kuliah Strategi Belajar Mengajar yang diketahui dari jawaban angket respon mahasiswa pada pertemuan I, II dan III dimana persentase pada beberapa pernyataan menjelaskan bahwa mahasiswa menjadi lebih aktif dalam proses belajar mengajar dengan menggunakan model pembelajaran kooperatif metode kancing warna.

2. Peningkatan partisipasi keaktifan mahasiswa terlihat dari jumlah mahasiswa yang berpartisipasi aktif dalam bentuk kegiatan mengajukan pertanyaan dalam diskusi, mengutarakan pendapat sebagai upaya untuk membantu kelompok presenter dalam menjawab serta beberapa sanggahan terhadap jawaban presenter yang mereka anggap kurang tepat. Pada pertemuan pertama mahasiswa yang berpartisipasi aktif dalam diskusi berjumlah 7 orang, pertemuan kedua sejumlah 15 orang dan pertemuan ketiga berjumlah 19 orang.

3. Peran dosen sebagai tenaga pendidik dalam upaya peningkatan mahasiswa semakin sedikit pada setiap pertemuan, hal tersebut merupakan salah satu bukti bahwa peningkatan partisipasi aktif mahasiswa dengan menggunakan model pembelajaran kooperatif menggunakan metode kancing warna dapat membantu upaya tersebut.

Hasil penelitian ini kemudian akan dijadikan bahan dalam peningkatan partisipasi keaktifan mahasiswa pada mata kuliah lain.

\section{SARAN}

Dalam melakukan penelitian tindakan kelas, sebaiknya melibatkan lebih dari satu observer, hal tersebut bertujuan agar partisipasi aktif siswa dapat terekam selengkapnya. Artinya, semakin banyak observer maka partisipasi siswa yang terjadi bersamaan dapat teramati sehingga data yang diperoleh lebih lengkap.

\section{DAFTAR PUSTAKA}

Afianti, N.W., Sulastry, T., Alimin. 2017. Penerapan Model Pembelajaran Kooperatif Tipe Kancing Gemerincing untuk Meningkatkan Keaktifan dan Hasil Belajar Peserta Didik Kelas X MIA 3 SMAN 1 Bontomarannu. Jurnal Nalar Pendidikan, 5 (2): 544.

Amelia, F dan Eva, M, G. 2014. Pengaruh Model Pembelajaran Kooperatif Teknik Kancing Gemercing Terhadap Hasil Belajar Siswa Pada Materi Pokok Zat dan Wujudnya. (Online), 2(4):19-23, (http://digilid.unimed.ac.id., diakses 6Maret 2019). 
Dani, Y.M., Maridi., Sugiharto, B. 2016. Peningkatan Keaktifan dan Motivasi Belajar Biologi melaluiDiscovery Learning pada Siswa Kelas XI IPA ICT 2 SMA Muhammadiyah 1 Karanganyar Tahun Pelajaran 2014/2015. BIO-PEDAGOGI: 5 (1): $1-5$.

Isjoni. 2012. Cooperative Learning, Mempraktekkan Cooperatif Learning di Ruang-ruang Kelas. Jakarta: Grasindo.

Asmani, J.M. 2011. Tips Pintar PTK: Penelitian Tindakan Kelas. Yogyakarta: Laksana.

Kagan, Spencer. 1998. Professional Development for Cooperative Learning: Issues and Approaches. Albany:State University of New York Press.

Karyana, E. 2013. Penerapan Model Kooperatif Tipe Kancing Gemercing Menggunakan Media Gambar Untuk Meningkatkan Menulis Cerita Rampang.(Online), 1(3):1-10, (http//:repository.upi.edu., diakses 6Maret 2019).

Kusnandar. 2012. Langkah Mudah Penelitian Tindakan Kelas. Jakarta: Grafindo

Hamdani, I. 2011. Strategi Belajar Mengajar. Bandung: Pustaka Setia.

Huda, M. 2011. Cooperative Learning: Metode, Teknik, Struktural, dan Model Penerapan. Yogyakarta: Pustaka Pelajar.

Robert. E Slavin. 2010. Cooperative Learning Teori, Riset dan Praktik. Bandung:Nusa Media

Sharan, S. 2012. The Handbook of Cooperative Learning. Yogyakarta: Familia.

Suprijono, A. 2011. Cooperative Learning Teori dan Aplikasi Paikem. Yogyakarta: Pustaka Pelajar

Untarti, R \& Kusuma, A. B. 2018. Meningkatkan Partisipsi Aktif
Mahasiswa melalui Lesson Study pada Mata Kuliah Geometri Uang. Jurnal Pendidikan Matematika dan IPA. 
